\begin{tabular}{c} 
Volume and Issues Obtainable at Center for Sustainability Research and Consultancy \\
Responsible Education, Learning, and Teaching in Emerging Economies \\
ISSN: $2708-4310$ (E): $2708-4183$ \\
Volume 2: No.2, December 2020 \\
CSRC \\
Journal homepage: www.publishing.globalcsrc.org/relate \\
\hline
\end{tabular}

\title{
Recreational and Leisure Time Activities Available for the Persons with Disabilities
}

*Samina Ashraf, Department of Special Education, University of the Punjab, Lahore, Pakistan
Bilal Hussain, Department of Special Education, University of the Punjab, Lahore, Pakistan
Zohaib Akram, Department of Special Education, University of the Punjab, Lahore, Pakistan

*Corresponding author's email: samina.dse@pu.edu.pk

ARTICLE DETAILS
History
Revised format: Nov 2020
Available Online: Dec 2020

Keywords

Leisure time, Persons with disabilities, Leisure time

JEL Classification:

I20, I23

\section{ABSTRACT}

Leisure time activities are defined as activities we perform in our free time. This study aims to explore the availability of leisure and recreational activities for persons with disabilities. The population of the study was special educationists, students of the different special schools of Lahore, and the people of the community who live in Lahore. A number of 30 persons with disabilities were selected through a convenient sampling technique from the higher educational institutes, special education institutions, and from the different areas of Lahore city. The study was conducted through the questionnaire the first part of the questionnaire was comprised of demographic information (Name, Age, Class, Gender, and school), and the second part comprised of 22 statements with the five-point Licker Scale. The scale was comprised of 5 options, 1=No, $2=$ Neutral, $3=$ Some-extent $4=$ Greater extent, and 5= Yes. The second part of the questionnaire was comprised of 22 statements about the availability of leisure and recreational activities in Lahore. Content validity of the instrument was estimated through experts' opinions relevant to the field of special education. Reliability was estimated through Cronbach alpha which was .75. Results showed that $86.7 \%$ of the respondents agreed upon that their school encourages their participation in leisure and recreational activities. A very good number of the respondents $90 \%$ agreed that they feel confident after leisure time activities. Conclusion: The study concluded that only a few and unvaried leisure time and recreational activities are available for persons with disabilities.

(C) 2020 The authors, under a Creative Commons AttributionNonCommercial 4.0

Corresponding author's email address: samina.dse@ pu.edu.pk

Recommended citation: Ashraf, S., Hussain, B. \& Akram, Z. (2020). Recreational and Leisure Time Activities Available for the Persons with Disabilities. Responsible Education, Learning and Teaching in Emerging Economies, 2(2), 59-64. 


\section{Introduction}

Recreational and Leisure time activities denote freely selected, single, or planned group events or actions that facilitate anybody to retain her/his good health physically. These activities have not only physical impacts rather, but these activities also embrace the psychological element of one's life that strengthens the will, determination, and improves the self-control of that person. Besides the psychological and physical facets of leisure time activities, numerous studies have put special emphasis on the significance of the socio-psychological aspect of recreation. Different studies have described recreation and leisure time activities in different ways. Some studies have included other activities in addition to physical activity( Ashwortha et al.,2009), physical exercising or playing sports, in recreational activities such as playing cards, playing computerbased games, reading books or journals, watching television, listening to music on the radio, etc. Solish et al. (2010) make a distinction between recreational and leisure activities or engagements. The activity is the performing of a task or action at the individual level, while participation is getting involved in any activity during a real-life situation (World Health Organization 2001). Leisureliness is normally comprised of such activities in which people participate to spend their free time according to their own choice and with enjoyment. People participate in such activities to make them relax and energetic (Majnemer et al. 2008). The benefits of participating in free time activities are remarkable for individuals of all ages. By reducing stress and anxiety, recreational and leisure activities impact the health, social wellbeing, learning ability, and personal development (Kampert and Goreczny 2007) of the persons who take part in such activities (Oia and Fauske, 2010).

Leisure activities have great importance in the lives of persons with disabilities (PWDs) as compared to persons without disabilities. According to Kambert and Goreczny(2007), they facilitate their relationship with normal peers and eases the social inclusion of persons with different disabilities. Nevertheless, persons with cognitive problems appear to engage at a smaller amount in free time fun activities with friends than persons (Solish et. al.,2010). The degree of engagement of intellectually challenged persons also decreases with the growth of their age (Wendelborg \& Paulsen, 2014).

Leisureliness has substantial impact on the mental health and general well-being of PWDs. Particularly for those who are two to three-time likely to overweight or obese due to a more inactive lifestyle. At the same time, persons with disabilities, especially those with severe level of disability, generally face more problems in initiating and managing a long term social linkage. In short, fun and relaxation activities are essential for the psychological, social, emotional and an overall development of PWDs.

The United Nations, in Article 30 of the rights of persons with disabilities has acknowledged the significance of taking part in leisure activities of such persons. The Article emphasizes that persons with disabilities should take part in recreation, cultural and sports events on the same terms as persons without disabilities (PWDs).

Besides the contribution of leisure time activities for the health and overall quality of life of persons with disabilities(King et al,.2003; Law et. al,2006), persons with disabilities participate less frequently in leisure time activities according to different research as compared to persons without disabilities (Michelsen et al.,2009; Shreuet, Sachs, \& Rosenblum, 2014; ShikakoThomas, Manjnemer, Law, \& Lach,2008).

The importance of leisure activities and their impact on the quality of life of children and adolescents with disabilities are evolving fields of research (Admsom2003; Majnemer, Shevell, Law, Rosenbaum \& Poulin 2006). The studies have shown that play is also used frequently as a therapeutic intervention for PWDs (Poulsen \& Ziviani, 2004). However, in certain cases, the play 
and recreation as the primary goal of the intervention were less evident. Knowledge on providing opportunities to children and youth with disabilities of different physical activities in their free time would enable therapists to expand interventions to include physical activities in leisure time and promote their health along with entertainment.

Participating in leisure time activities is a challenging task for persons with disabilities. For instance, persons with intellectual limitations seem to experience widespread hurdles to leisure than other types of PWDs (Molden and Tossebro 2009). These hurdles include costs to adapt to the public places according to the needs of persons with disabilities, deficient assets to adapt their interests, challenges of transportation, and attitude of the community members towards the persons with disabilities (Fuchs, \& Gilboa, 2018).

\section{Significance of the Study}

Everybody needs leisure time to manage anxiety and stress in their life. Leisure helps re-energize and relax people, who can perform activities well in their lives. Persons with different disabilities can increase in their fun and entertainment engagements after knowing the importance of such activities in the light of this research. PWDs can indeed improve their ability by involving them in different leisure activities. It will helps them to raise logical thinking and solve their problems more effectively. On the other hand, the state parties can upgrade the opportunities of leisure time for PWDs through extending existing facilities of entertainment like cinemas, parks and theaters etc.

\section{Impact of the Study}

This study will have an impact on the quality of leisure and recreational leisure activities for PWDs by emphasizing the problems they are experiencing in accessing leisure and recreational activities. This study will brief the community about the leisure and recreational needs of PWDs.

\section{Research Objectives}

This study has the following major objectives:

1. Explore the leisure time and recreational activities available for persons with disabilities(PWDs) at Lahore.

2. Identify the available resources of recreational and leisure activities for PWDs.

3. To find out the difference between the opinions of the respondents on the basis of their gender on the availability of leisure time and recreational activities.

\section{Method and Procedure}

This study was conducted on recreational and leisure time activities available for PWDs in Lahore by applying descriptive research design.

A self-reported survey was steered for the data collection. The instrument of this study was a questionnaire. The instrument (questionnaire) was divided into two parts: the first part was related to demographic information and the second part related to 22 statements about the availability of leisure and recreational activities in Lahore city for persons with disabilities. Each of the statement has five options to acquire the responses from the respondents in a Licker Scale fashion to i.e., Greater extent, Some-extent, Neutral, Yes, and No. The Cronbach alpha was run to check the reliability of the instrument of this study that was (.75). The targeted population of the study consisted of persons with disabilities living in Lahore city and different students of special schools of Lahore. The population of the study was 30. All of the respondents were taken as a samples through convenient sampling technique. The consent of the participants was assured before the data collection through telephonic calls. The data were also collected through Eresources like Google form E-mail and Whatsapp. IBM version 21 was applied to analyze the data. The frequency of the replies (of the PWDs) along with their ratio was calculated. 


\section{Results}

The frequency of the responses along with their percentages is tabulated and presented in the following table.

\begin{tabular}{|c|c|c|c|c|c|c|c|c|c|c|c|}
\hline $\begin{array}{l}\text { Sr. } \\
\text { No. }\end{array}$ & Statement & $\begin{array}{l}\text { Greater } \\
\text { extent }\end{array}$ & $\%$ & $\begin{array}{l}\text { Some } \\
\text { extent }\end{array}$ & $\%$ & Neutral & $\%$ & Yes & $\%$ & No & $\%$ \\
\hline 1. & $\begin{array}{l}\text { Have you ever participated in } \\
\text { leisure time activities? }\end{array}$ & $\begin{array}{l}------- \\
\end{array}$ & $\begin{array}{l}--- \\
\end{array}$ & 20 & 90 & --------- & ---- & 1 & 4.5 & 9 & 41 \\
\hline 2. & $\begin{array}{l}\text { Do you face barriers while } \\
\text { participating in leisure activities? }\end{array}$ & -------- & ---- & 19 & 86 & 5 & 22 & 6 & 27 & ---- & ---- \\
\hline 3. & $\begin{array}{l}\text { Have you attended any } \\
\text { independence day celebrations in } \\
\text { Lahore? }\end{array}$ & -------- & $\begin{array}{l}--- \\
\end{array}$ & 10 & 45 & 8 & 36 & 12 & 54 & $\begin{array}{l}--- \\
\end{array}$ & $\begin{array}{l}--- \\
\end{array}$ \\
\hline 4. & $\begin{array}{l}\text { Have your area adapted parks for a } \\
\text { person with disabilities? }\end{array}$ & -------- & ---- & 10 & 45 & 12 & 54 & 8 & 36 & ---- & ---- \\
\hline 5. & $\begin{array}{l}\text { Have you visited any books fair in } \\
\text { your city? }\end{array}$ & -------- & ---- & 12 & 54 & 1 & 4 & 15 & 68 & 2 & ---- \\
\hline 6. & $\begin{array}{l}\text { Are there adapted seats available for } \\
\text { the persons with disabilities in the } \\
\text { cinemas? }\end{array}$ & 1 & 4 & 6 & 27 & 19 & 86 & 4 & 18 & ---- & ---- \\
\hline 7. & $\begin{array}{l}\text { Are there adapted ramps and } \\
\text { walkways for the persons with } \\
\text { disabilities in the parks? }\end{array}$ & -------- & ---- & 17 & 77 & 7 & 31 & 6 & 27 & ---- & ---- \\
\hline 8. & $\begin{array}{l}\text { Have public libraries adapted } \\
\text { facilities for persons } \\
\text { disabilities? }\end{array}$ & -------- & ---- & 15 & 68 & 11 & 50 & 3 & 13 & 1 & 4 \\
\hline 9. & $\begin{array}{l}\text { Are persons available in restaurants } \\
\text { to help you? }\end{array}$ & -------- & ---- & 22 & 100 & 3 & 13 & 3 & 13 & 2 & 9 \\
\hline 10. & $\begin{array}{l}\text { Do you daily participate in leisure } \\
\text { activities? }\end{array}$ & 1 & 4 & 12 & 54 & 1 & 4 & 16 & 72 & ---- & ---- \\
\hline 11. & $\begin{array}{l}\text { Have you ever participated in } \\
\text { running recreation activities? }\end{array}$ & -------- & ---- & 13 & 59 & 4 & 18 & 12 & 54 & 1 & 4 \\
\hline 12. & $\begin{array}{l}\text { Does your institution encourage } \\
\text { your participation in leisure and } \\
\text { recreational activities? }\end{array}$ & ---- & ---- & 20 & 90 & 3 & 13 & 59 & ---- & 4 & 18 \\
\hline 13. & $\begin{array}{l}\text { Have you ever enjoyed } \\
\text { backpacking? }\end{array}$ & -------- & ---- & 13 & 59 & 1 & 4 & 14 & 63 & 2 & 9 \\
\hline 14. & $\begin{array}{l}\text { Do you take part in leisure time } \\
\text { activities arranged by your } \\
\text { academic institution? }\end{array}$ & 3 & 13 & 21 & 95 & 4 & 18 & ---- & ---- & 2 & 9 \\
\hline 15. & $\begin{array}{l}\text { Are there adapted swimming pools } \\
\text { available for persons with } \\
\text { disabilities? }\end{array}$ & 1 & 4 & 7 & 31 & 19 & 86 & 2 & 9 & ---- & ---- \\
\hline 16. & $\begin{array}{l}\text { Is there any concession in ticketing } \\
\text { of the parks, cinemas, and theaters } \\
\text { for persons with disabilities? }\end{array}$ & $-\cdots$ & ---- & 18 & 81 & 11 & 50 & 1 & 4 & ---- & ---- \\
\hline 17. & $\begin{array}{l}\text { Is there any facility for an adapted } \\
\text { dinning-table in the hotels for } \\
\text { persons with disabilities? }\end{array}$ & -------- & ---- & 2 & 9 & 16 & 72 & 11 & 50 & 1 & 4 \\
\hline 18. & $\begin{array}{l}\text { Have you ever participated in } \\
\text { camping with your friends? }\end{array}$ & |-------- & ---- & 7 & 31 & 3 & 13 & 20 & 90 & ---- & ---- \\
\hline 19. & $\begin{array}{l}\text { Do you feel confident after leisure } \\
\text { activities? }\end{array}$ & '-------- & ---- & 21 & 95 & & & 6 & 27 & 3 & 13 \\
\hline 20. & $\begin{array}{l}\text { Do you think participating in } \\
\text { recreational activities improves your } \\
\text { physical and psychological well- } \\
\text { being? }\end{array}$ & -------- & ---- & 19 & 86 & 1 & 4 & 1 & 4 & 9 & 40 \\
\hline
\end{tabular}




\begin{tabular}{|c|c|c|c|c|c|c|c|c|c|c|c|}
\hline 21. & $\begin{array}{l}\text { Are any resources/helping persons } \\
\text { available in public parks to help } \\
\text { you? }\end{array}$ & -------- & ---- & 20 & 90 & 3 & 13 & 59 & & 7 & 31 \\
\hline 22. & $\begin{array}{l}\text { Have you ever get benefited from } \\
\text { indoor (Halls) or outdoor (Parks) } \\
\text { facilities available in the } \\
\text { community? }\end{array}$ & -------- & ---- & 4 & 18 & 10 & 45 & 16 & 72 & ---- & ---- \\
\hline
\end{tabular}

Table No.1: Frequency of the responses

The above table shows that the majority of the respondents $(76.6 \%)$ have shown neutral response against the item on availability of adapted swimming pools for the persons with disabilities, $(66.7 \%)$ of the respondents agreed upon that helping persons are not available in public parks to help them, whereas (73.3\%) agreed upon that some persons are available in restaurants to help them, $(86.7 \%)$ of the respondents agreed upon that their institutions encourage their participation in leisure and recreational activities. A very good number of the respondents $(90 \%)$ agreed that they feel confident after leisure time activities.

The above table shows that most of the respondents $(66.7 \%)$ disagree that they have not ever participated in leisure time activities, $(53.3 \%)$ disagreed that they do not daily participate in leisure activities, $(86.7 \%)$ disagreed that they have ever enjoyed backpacking, (53.3\%) of the respondents disagreed that they get to benefit from indoor (Halls) or outdoor (Parks) facilities available in the community.

The Independent sample t-test was run to see the difference between the opinion of male and female respondents about available recreational and leisure time activities.

Table No.2: Independent sample t-test.

\begin{tabular}{|l|l|l|l|l|}
\hline Gender of the Respondent & $\mathrm{N}$ & Mean & Std. Deviation & Sig \\
\hline Male & 16 & 59.63 & 2.729 & .417 \\
\hline Female & 14 & 58.71 & 3.245 & \\
\hline
\end{tabular}

The above table shows an insignificant variance between the female and male respondents on the obtainability of leisure time engagements.

\section{Conclusion}

The whole study concluded recreational and free time fun engagements have influenced the lives of persons with special needs. Besides the fact that provision of leisure and recreation, services enhance the capabilities and abilities of persons with special needs. Children with different disabilities feel comfortable and confident after involvement in free time and recreational engagements. The participation of students with special needs in recreation activities improves their psychological and physiological well-being. Recreational and leisure activities reduce the social isolation of the students with special needs and students also feel good and enthusiastically do their work. Parents of special children also feel better to see their children confident after participation in leisure and recreational activities. However, the respondents stated that there is a lack of resources and facilities available for leisure and recreational activities for persons with disabilities.

\section{Recommendation of the study}

The recommendations of the study are given below.

1. The state needs to provide recreational and free time engagements in a various areas.

2. The recreational and leisure time resources should be adapted according to the needs of persons with disabilities. 


\section{References}

Allock, A. (2018, September). Disability and access to leisure. Iriss esss, 1-24.

Brady, A., Christensen, K., \& Holt, J. (2015). The changing view of physical recreation for people with disabilities in the USA. Review of Disability Studies: An International Journal, 13(2), 1-16.

Chiarello, L. A., Palisano, R. J., McCoy, S. W., \& Alghmadi, M. S. (2017, 1 10). Understanding participation of children with cerebral palsy in family and recreational. Physical Therapy Publications, 1-32.

Demirci, P. T. (2019). Recreational activities for with disability: school-aged children and adolescents. International Journal of Recreation and Sport Science, 3(1), 46-57.

Eratay, A. (2013, August). Effectiveness of leisure time activities program on social skills and behavioral problems in individuals with intellectual disabilities. Academic Journals, 8(16), 1437-1448.

Ferreira, M. S., Alves, S., Maia, M. S., Gomes, M., Santos, B., \& Santos, P. d. (2018). A comparison between children and without disabilities in Portugal. European Journal of Educational Research, 8(1), 221-232.

Fiorentino, L., Gentle, D., Hall, D., Harpine, V., Philips, D., \& Walker, A. (1998). Transition from school to adult life for physically disabled young people. Arch Dis Chil, 79, 306-311.

Fuchs, R., \& Gilboa, Y. (2018). Participation patterns of pre-school children with Intellectual developmental disabilities. Occupation, Participation and Health, 1-8.

Melboe, L., \& Ytterhus, B. (2014). Disability Leisure: In what kind of activities, and how do youths with intellectual disabilities participate? 1-19.

Ozkara, B. A. (2018, December 12). Recreational activities for people with disabilities; a traditional systematic review. International Journal of Scientific and Research Publications, 884-888.

Potic, S., Stanimirov, K., Dordevic, M., \& Bankovic, S. (2014, January). Physical-recreational activities for persons with disabilities. Potic, S.et.al, 8, 71-80.

Roult, R., Carbonneau, H., Ranger, E. B., Onge, M. S., Brunet, I., \& Adjizan, J. M. (2017). Leisure for people with disabilities in rural Quebec Societies, 1-18.

Saebu, M. (2009). Physical disability and physical activity. European Journal of Adapted Physical Activity, 3, 37-55.

Schwarzenegger, A., \& Chrisman, M. (2005). The health and socail benefits of recreation. 1 .

Steinhardt, F., Ullenhag, A., Jahnsen, R., \& Dolva, S. A. (2019, December). Perceived facilitators and barriers for participation in leisure activities in children with disabilities: perspectives of children parents and professionals. Scandinavian Journal of Occupational Therapy, 1-16.

Targett, P., Wehman, P., West, M., Dillard, C., \& Cifu, G. (2013). Promoting transition to adulthood for youth with physical disabilities and health impairments. Journal of Vocational Rehabilitation, 39, 229-239.

Thomas, K. S., Majnemer, A., Law, M., \& LacH, L. (2008). Determinants of participation in leisure in children and youth with cerebral palsy. Physical and Occupational Therapy in Pediatrics, 155-169.

Wray, L., P, J., \& Y, L. (2014). Social relationships, leisure activity and health in older adults. Health Psychology, 33, 516-523.

Wright, S. A. (May 2007). Accessibility of recreational sports for students with disabilities at the University of the western cape. Western Cape: University of the Western Cape.

Zull, A., Tillmam, V., Frobose, I., \& Anneken, V. (2019). Physical activity of children and youth with disabilities and the effect on participation in meaningful leisure-time activities. Cognet Social Sciences, 1-16. 